\title{
Heterogeneity of Top Management Team and Earnings Management: An Empirical Analysis of A-Share Listed Companies during 2010-2017
}

\author{
Mian Kou ${ }^{1}$ \\ ${ }^{1}$ Beijing jiaotong University, China
}

\begin{abstract}
The behavior of corporate earnings management is an important factor restricting the development of the industry. Based on the senior echelon theory, TMT's demographic characteristics such as the cognitive basis, observation, values and other characteristics, affect their strategic decisions, and thus affect the company's performance and development of the industry. This paper selected 3588 listed companies from 2010-2017 using the revised Jones model to measure the earnings management degree of listed companies, and analyzed the impact of senior management team members on enterprise earnings management in three dimensions of age, education level and professional background. The study found there is no obvious correlation between the age heterogeneity of TMT and the degree of earnings management; the heterogeneity of the education level and the heterogeneity of professional background have a significant negative correlation with the degree of earnings management. This study can improve the corporate governance structure, promote the reform of the market supervision mechanism, protect the rights and interests of investors, and then promote the healthy development of the industry.
\end{abstract}

\section{Introduction}

In the modern corporate enterprises, there are serious agency problems between shareholders and managers, and a large number of enterprises have financial fraud, profit operation, trying to beautify the performance through earnings management, seriously damage the rights and interests of small and medium shareholders, disrupt the order of China's capital market, and make the authenticity of the annual financial information disclosure constantly questioned by investors.

For a company, its earnings data is an important part of the financial statements, directly affecting the decisions of the stakeholders. In academic research, earnings management is also one of the key topics of scholars, a large number of related researches choose type, motivation, influencing factors, analyze and discuss the company's earnings management behavior, calculate earnings management degree, analyze the economic consequences, but such researches ignore the implementation subject of earnings management behavior ---- top management team members.

The executive team, as a leader in developing and implementing important strategic decisions, plays a decisive role in the company's performance and development. Based on the theory of senior echelon, many scholars at home and abroad have begun to pay attention to the relationship of executive team characteristics and company accounting behavior. The team of executives takes demographic characteristics as the cognitive basis, observation, values and other characteristics of external performance, as well as the homogeneity and heterogeneity characteristics of the whole team background, which will affect their strategic decisions, thus affecting the behavior and performance of the company, and acting on the production of earnings management behavior.

Previous academic studies have mostly taken the homogeneity of the characteristics, and mainly focused on the relationship between the management background and the company's organizational results, such as corporate performance, social disclosure, and investment efficiency. This paper selects three dimensions of age, education level, and professional background to study the relationship between heterogeneous characteristics and earnings management, and puts forward more effective practical guidance for the construction of the functional background characteristics of TMT of listed companies. In the empirical part of the article, we believe that other explanatory variables in multivariate linear regression will also affect the regression process of current explanatory variables, so this paper regresses all independent variables and dependent variable together in a model.

\footnotetext{
*Corresponding author: reverse9991@163.com
} 


\section{Literature review and theoretical assumptions}

\subsection{Study on the Heterogeneity and Earnings Management of the Executive Team}

The senior echelon theory believes that the background characteristics of the executive team have an impact on the behavior selection and performance of the enterprise. Tihanyi et al found that when the characteristics of TMT are related to the enterprise diversification strategy selection, the higher the age and term heterogeneity is, the more inclined to choose the diversification strategy[1]. Xie Zhiming (2014) who based on the revised Jones model, through the study of A-share listed company data, found that the senior team age heterogeneity of management weakens the earnings management behavior of the company, and education level and term heterogeneity will enhance the company's earnings management motivation, gender heterogeneity and earnings management are basically not related[2]. He Weifeng (2015) proposed that the gap in the education level of the chairman and general manager is positively related to the degree of earnings management of the company, and the term difference suppresses the earnings management, with no obvious impact on the age difference[3].However, some scholars have reached different conclusions, such as Zhou Xiaohui (2017) also based on the senior echelon theory, the results of the correlation shows that the term heterogeneity weakens the earnings management motivation, and the heterogeneity of education level and age enhances the earnings management motivation[4].

In conclusion, the research on senior team heterogeneity and earnings management is mainly focused on the dominant variables of senior management team, instead of the hidden variables such as term, education, industry background, and especially lacks empirical papers; and the relationship between senior team age, career background and education level and earnings management has not been concluded. The literature on how executive team characteristics affect earnings management mostly only study the relationship from the homogeneity of a single background feature and lack of overall research on heterogeneity. Therefore, this paper starts with the empirical research between the heterogeneity and earnings management of listed companies in China, and provides some new research evidence for future academic research.

\subsection{Research assumptions}

\subsubsection{Age heterogeneity and Earnings Management}

Managers at different ages, their life characteristics and social and historical events, creating different decisionmaking styles and risk preferences, young executives dare to innovate, aggressive decisions, have the courage to undertake high growth and high risk; senior executives are constrained by high salary and stable career, tend to robustness in important strategic decisions, generating financial restatement. The optimization and integration of executives of different ages into a team is conducive to giving play to their own advantages, complementary information; the mutual restraint is more conducive to avoid the company's extreme decision-making. In the sense, the improvement of decision-making quality can play a inhibit on the company's earnings management.

Therefore, hypothesis 1 is proposed that the age heterogeneity of TMT is significantly negatively related with the degree of earnings management of listed companies.

\subsubsection{Education Level Heterogeneity and Earnings Management}

The degree of education is related to the knowledge level and professional quality to a certain extent. In the choice of whether to handle financial data, high educated managers are more likely to identify their potential risk and adverse impact and tend to avoid earnings manipulation; while low educated managers are limited by their own cognitive level and easy to be confused by the short-term benefits brought by earnings manipulation, and it is difficult to have deep cognition and affect correct decision-making.

hypothesis 2 : the educational heterogeneity of the senior executive team is significantly positively correlated to the degree of earnings management of listed companies.

\subsubsection{Career Background Heterogeneity and Earnings Management}

The understanding of the environment is the basis of the manager decision-making. The managers with different professional backgrounds have different cognition and understanding of the social environment and market environment, different professional experience, and the decision-making will also have different preferences. This heterogeneity feature also enhances the information asymmetry in the management team, and the earnings management decisions will be directly influenced by different ways of communication, thinking patterns, and risk preferences.

hypothesis 3: the heterogeneity of the professional background of the senior executive team is significantly positively correlated to the degree of earnings management of listed companies.

\section{Research and Design}

\subsection{Data source and screening}

The research object of this paper is the A-share listed company, with 2010-2017 as the sample range. The data mainly comes from the CSMAR database, enterprise annual report and manual sorting, and excluded: (1) ST company; (2) the listed company in the financial and insurance industry; (3) the company with severely missing data. Finally, 12360 sample data of 3588 listed companies in seven years were obtained, and the Winsorize method 
was used to shrink the upper and lower extremes of $1 \%$ of the variables.

\subsection{Variable design}

Considering the availability of data, the measurement of management background characteristics includes age, education level and vocational background. In order to eliminate the influence of irrelevant factors and more accurately study the correlation between manager heterogeneity and enterprise earnings management, this paper selects enterprise scale, first shareholder shareholding ratio, executive team size, net profit growth rate as the control variables. Table 1 shows the relevant variables as defined in detail.

This paper takes the absolute value (ABS DA) of handling accrual earnings management (DA) as the proxy variable indicating the degree of earnings management of listed companies, according to the revised Jones model in the Red Star (2017) [5]study:

$$
\begin{gathered}
T A_{\mathrm{it}}=N I_{\mathrm{it}}-C F O_{\mathrm{it}} \\
T A_{\mathrm{it}} / A_{\mathrm{it}-1}=\beta_{0} / A_{\mathrm{it}-1}+\beta_{1}\left(\Delta R E V_{\mathrm{it}-}-\Delta R E C_{\mathrm{it}}\right) / A_{\mathrm{it}-1}+\beta_{2} \\
P P E_{\mathrm{it}} / A_{\mathrm{it}-1}+\varepsilon_{\mathrm{it}}(2)
\end{gathered}
$$

$T A_{\text {it }}$ represents total accrued profit for the t-year, $N I_{\text {it }}$ represents net profit for year t, $C F O_{\text {it }}$ represents cash flow from operating activities in year t, $A_{\text {it- } 1}$ represents total assets at the end of year $\mathrm{t}-1, \triangle R E V_{\text {it }}$ represents year-t and $\mathrm{t}-1$ year main business income difference, $\triangle R E C_{\text {it }}$ represents the difference in accounts receivable in year $\mathrm{t}$ and $\mathrm{t}-1, P P E_{\text {it }}$ represents the value of fixed assets at the end of year $\mathrm{t}, \beta_{0}, \beta_{1}, \beta_{2}$ are the feature parameters, and $\varepsilon_{\text {it }}$ is the residual, or DA.

Table1. Variable definition

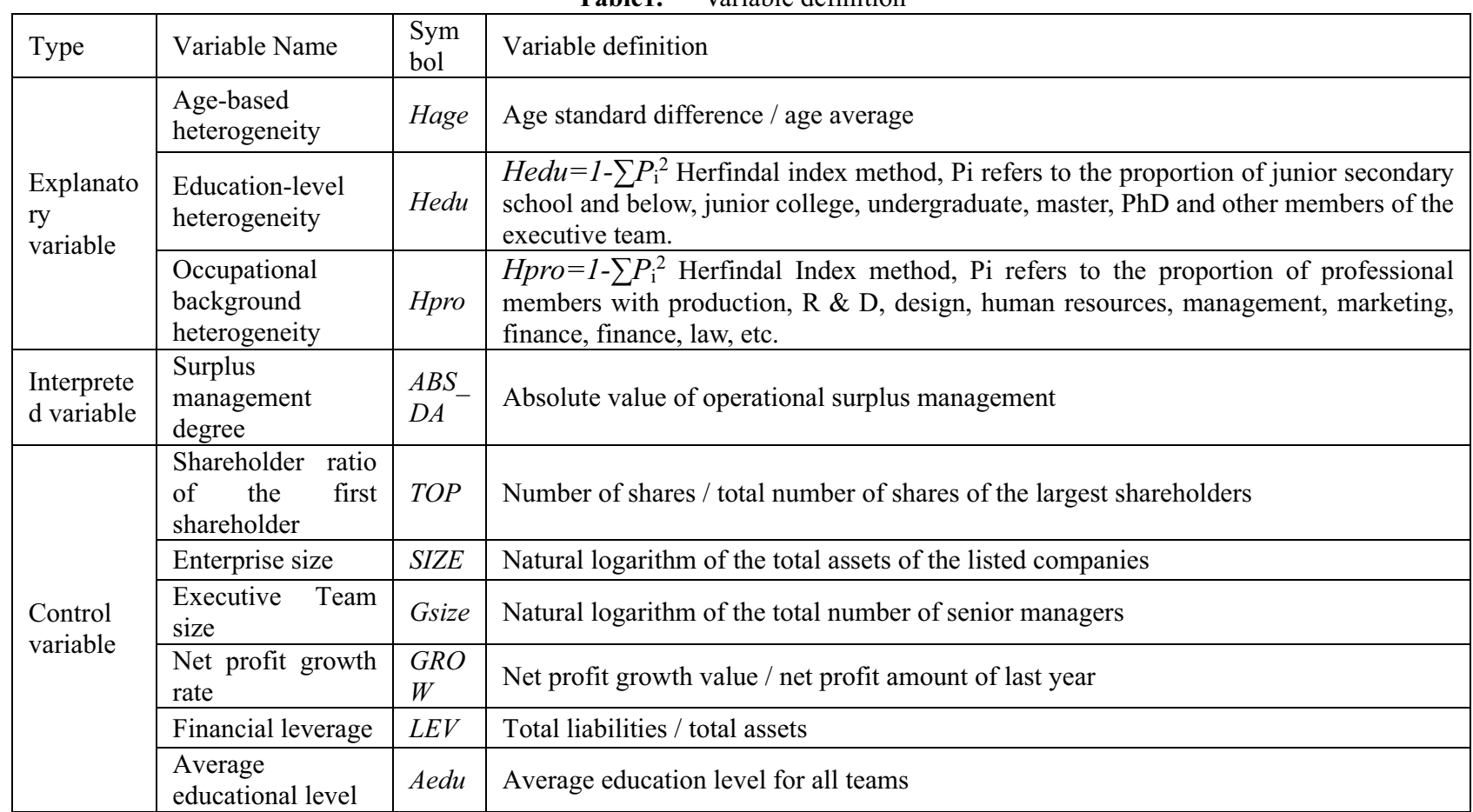

\subsection{Model design}

Build multivariate linear regression models to measure the impact of the heterogeneity of the executive team age, education level, and career background on corporate earnings management:

$$
\begin{array}{r}
A B S \_D A=\alpha_{0}+\alpha_{1} H a g e+\alpha_{2} H e d u+\alpha_{3} H \text { Hro } \\
\beta \sum C O N T R O L+\varepsilon_{\mathrm{i}}(3)
\end{array}
$$

The CONTROL stands for all the control variables.

\section{Empirical research, analysis and inspection}

\subsection{Descriptive Statistics}

Table 2 lists descriptive statistics for all variables of the full sample company from 2011 to 2017 . the average value of ABS_DA is 0.030 and the maximum value is 0.059 , indicating the common accrual earnings management behavior of the sample company. Among the heterogeneity of the executive team, the occupational background has the average value of 0.850 , indicating the difference; the education level is 0.638 , the minimum is 0.742 , indicating the diversity; the average age heterogeneity is the lowest, 0.154 and the standard difference of 0.037 , indicating the small age difference of the executive team members of the listed company. 
Table2. Descriptive Statistical Results

\begin{tabular}{|c|c|c|c|c|}
\hline $\begin{array}{c}\text { Variable } \\
\text { Name }\end{array}$ & $\begin{array}{c}\text { Average } \\
\text { value }\end{array}$ & $\begin{array}{c}\text { Standard } \\
\text { difference }\end{array}$ & $\begin{array}{c}\text { Minimum } \\
\text { value }\end{array}$ & $\begin{array}{c}\text { Maximum } \\
\text { value }\end{array}$ \\
\hline ABS_DA & 0.030 & 0.019 & 0.000 & 0.059 \\
\hline Hage & 0.154 & 0.037 & 0.098 & 0.213 \\
\hline Hedu & 0.638 & 0.078 & 0.5 & 0.742 \\
\hline Hpro & 0.850 & 0.055 & 0.735 & 0.91 \\
\hline TOP & 34.266 & 12.575 & 16.990 & 55.240 \\
\hline SIZE & 21.970 & 0.984 & 20.618 & 23.685 \\
\hline Gsize & 2.753 & 0.299 & 2.197 & 3.178 \\
\hline Grow & 0.019 & 0.625 & -1.094 & 1.077 \\
\hline LEV & 0.403 & 0.188 & 0.134 & 0.698 \\
\hline Aedu & 3.355 & 0.357 & 2.750 & 3.857 \\
\hline
\end{tabular}

\subsection{Regression analysis}

Table3. Reression Results

\begin{tabular}{c|c|c}
\hline COEFFICIENT & ABS_DA & $t$ \\
\hline Hage & 0.00627 & $(1.30)$ \\
\hline Hedu & $-0.00712^{* * *}$ & $(-3.21)$ \\
\hline Hpro & $-0.0225^{* * *}$ & $(-6.24)$ \\
\hline TOP & $0.0000279^{* *}$ & $(2.11)$ \\
\hline SIZE & $0.00176^{* * *}$ & $(8.18)$ \\
\hline Gsize & $0.00145^{* *}$ & $(2.18)$ \\
\hline Grow & -0.0000451 & $(-0.17)$ \\
\hline LEV & $0.00926^{* * *}$ & $(8.76)$ \\
\hline Aedu & $0.00414^{* * *}$ & $(8.41)$ \\
\hline Constant & -0.00853 & $(-1.60)$ \\
\hline R-squared & 0.05 & \\
\hline r 2 a & 0.0489 & \\
\hline F & 71.63 & \\
\hline t statistics in parentheses & $* * * \mathrm{p}<0.01, * * \mathrm{p}<0.05 * \mathrm{p}<0.1$
\end{tabular}

t statistics in parentheses $\quad * * * \mathrm{p}<0.01, * * \mathrm{p}<0.05, * \mathrm{p}<0.1$

Table 3 shows the return results of executive team heterogeneity and earnings management.The regression coefficient of the executive team age heterogeneity is 0.00627 , The $t$ value is 1.30 , There is no correlation with the explained variables, The conclusion that the age heterogeneity of TMT of listed companies has no significant impact on earnings management and is not consistent with hypothesis 1 ; the regression coefficient of both the executive team education level and the occupational background heterogeneity were significantly negative at the $1 \%$ level, Regression coefficient are0.00712 and -0.0225 , The $t$ value is-3.21, and -6.24 , To demonstrate that the educational level and occupational background will weaken the degree of earnings management, In stent with assumptions 2 and 3 .

The regression results of the control variables indicate that the first shareholder shareholding ratio, enterprise size, executive team size, financial leverage and education levels are all significantly positively correlated with accrued earnings management. The higher the shareholding proportion of the first shareholder represents that the higher the controlling shareholder has control over the company, which increases the possibility of earnings management. The positive correlation between enterprise size and earnings management confirms that the greater the company size of the current earnings delay, the greater the possibility to avoid high profits from receiving regulation. The positive correlation between financial leverage and earnings management shows that the higher the company's asset-liability ratio, the greater the financing constraints, the more likely to take accrued earnings management to avoid the cost of default.

\subsection{Robustness test}

The robustness test in this paper is to replace the control variable, select the growth rate of the main business income to replace the net profit growth rate, and return to the overall sample, the conclusions are basically consistent with this paper, indicating that the research conclusions of this paper have robustness.

\section{Research conclusions and suggestions}

This paper selects the age, education level and vocational background of executive team members to measure the background characteristics, using the Herfind-ahl index, and the modified Jones model to establish a regression model and study the influence of management heterogeneity on the earnings management behavior from 2010-2017. The research conclusions are as follows:

(1) Age heterogeneity and earnings management are not obviously related, possibly because the managers are at different ages, different decision style and risk preferences, complementary information, mutual constraint to avoid extreme decision making, decision quality inhibit earnings management in management ideas and ways, resulting in poor team cooperation and communication, and the improvement of information asymmetry creates conditions for earnings management. The two actions contribute to unrelated results of age heterogeneity and earnings management.

(2) Executive team education level heterogeneity and will weaken the degree of earnings management.

(3) The professional background of the executive team weakens the degree of earnings management.

Therefore, we suggest that when allocating TMT, the listed companies can select the senior management members with multi-level education level and diversified professional background, so as to improve the heterogeneity of the education level of the management team. The differentiation of these two gives the company diversified resource channels and sources of experience. Senior executive members play with each other to their respective advantages, actively communicate with different schemes, reduce information asymmetry, improve the efficiency of decision-making and quality, and promote the long-term development of the enterprise.

\section{References}

1. Laszlo, T., et al. Composition of the Top Management Team and Firm International Diversification[J]. Journal of Management 26(2000)

2. Xie ZM, et al. Impact of Management heterogeneity on Corporate Surplus Management _ Based on Empirical A Share Listed Companies 2009-2011 [J]. Journal of Central South University, 20 (2014): 
3. He WF. Study on Vertical Characteristics and Enterprise Surplus Management Behavior of the Executive Team [J]. Nankai Management Review, 18 (2015)

4. Zhou XH, et al. Executive Team heterogeneity, Surplus Management and Corporate Performance [J]. Journal of Nanjing Audit University, 14 (2017)

5. Fang HX, Liu SH. Earnings Management and Corporate Debt Term [J]. Financial Issues Studies, (2017) 